\title{
REVIEW
}

\section{Antiangiogenic therapies for pheochromocytoma and paraganglioma}

\author{
Camilo Jimenez', Sasan Fazeli1 and Alejandro Román-Gonzalez2,3 \\ 1Department of Endocrine Neoplasia and Hormonal Disorders, The University of Texas MD Anderson Cancer Center, Houston, Texas, USA \\ 2Department of Endocrinology and Diabetes, Universidad de Antioquia, Medellin, Colombia \\ ${ }^{3}$ Department of Endocrinology, Hospital Universitario San Vicente Fundacion, Medellin, Colombia
}

Correspondence should be addressed to C Jimenez: cjimenez@mdanderson.org

\begin{abstract}
Metastatic pheochromocytomas and paragangliomas are rare, highly vascular tumors that spread primarily to the lymph nodes, skeletal tissue, lungs, and liver. Tumor morbidity is related to their size, location, hormonal activity, vascular nature, and rate of progression. Systemic therapies for this indication are limited. Only high-specific-activity iodine-131 metaiodobenzylguanidine is approved in the Unites States for treatment of these patients, and not all patients are candidates for this radiopharmaceutical. Antiangiogenic medications are currently being evaluated in prospective clinical trials for patients with metastatic pheochromocytomas and paragangliomas, and preliminary results have been encouraging. Antiangiogenic medications frequently offer antineoplastic effects with sometimes durable responses. However, cardiovascular toxicity and the development of tumor resistance may limit their efficacy. Experience derived from clinical trials is being used to identify mechanisms to effectively improve drug toxicity and possibly prevent the emergence of resistance. Therefore, antiangiogenic medications represent a therapeutic option for patients with metastatic pheochromocytomas and paragangliomas. Furthermore, in the world of oncology, there is strong scientific interest in the development of clinical trials that combine antiangiogenic medications with other modalities such as immunotherapy, radiopharmaceuticals, and hypoxia inhibitors since these combinations may substantially enhance clinical outcomes, including survivorship. In this review, we examine the progress made to date on antiangiogenic treatments for patients with metastatic pheochromocytomas and paragangliomas.
\end{abstract}

Key Words

- pheochromocytoma/ paraganglioma

- succinate dehydrogenase subunit B

- angiogenesis

- systemic therapy

- tyrosine kinase inhibitors

- objective response rate

- progression free survival

- toxicity

\section{Introduction}

Pheochromocytomas and paragangliomas are neuroendocrine tumors that make up less than $1 \%$ of all endocrine neoplasias. Pheochromocytomas and paragangliomas arise from the adrenal medulla and the extra-adrenal paraganglia, respectively (Lam 2017). Pheochromocytomas are sympathetic tumors that commonly release catecholamines such as noradrenaline and/or adrenaline. Paragangliomas are classified as parasympathetic or sympathetic, depending on the autonomic nervous system ganglia of origin. Parasympathetic paragangliomas are located primarily in the head and neck and do not release catecholamines. These tumors are frequently asymptomatic and are discovered during routine physical examination or accidentally by imaging studies. Sympathetic paragangliomas are located in the thorax, abdomen, and pelvis and frequently release
C) 2020 Society for Endocrinology Published by Bioscientifica Ltd. Printed in Great Britain 
excessive amounts of noradrenaline (Lam 2017). Unlike parasympathetic paragangliomas, pheochromocytomas and sympathetic paragangliomas predispose to hormonal symptoms such as hypertension, palpitations, sweats, headaches, and diabetes mellitus. These symptoms are not specific, and the diagnosis is frequently overlooked. A high index of suspicion is essential to discover these tumors (Manger 2009).

Most pheochromocytomas and paragangliomas are curable with surgery (Lenders et al. 2014). However, $15-20 \%$ of these tumors are metastatic. Unfortunately, there is no histological, molecular, biochemical, or genetic predictor of the tumor's metastatic potential. The World Health Organization (WHO), however, recognizes that all pheochromocytomas and paragangliomas have the potential to spread distantly and recommends that the term 'malignant' be avoided in this setting, for example, 'metastatic tumor' is preferred to 'malignant tumor' (Lam 2017). Most patients with metastatic tumors present with advanced disease, and their lifespan is usually compromised. Metastases happen in less than $10 \%$ of parasympathetic paragangliomas, in up to $25 \%$ of pheochromocytomas, and in $40-70 \%$ of sympathetic paragangliomas (Ayala-Ramirez et al. 2011, Hamidi et al. 2017, Jasim \& Jimenez 2019). Metastatic pheochromocytomas and paragangliomas (MPPGs) spread mainly to the lymph nodes, skeletal tissue, lungs, and liver and exhibit variable aggressiveness. Metastases may be present at the time of diagnosis or may become apparent after the discovery of the primary tumor (Jimenez et al. 2013, Roman-Gonzalez \& Jimenez 2017). Patients with MPPGs frequently exhibit a large tumor burden with overwhelming symptoms of catecholamine excess. Difficult to control hypertension, acute and chronic cardiovascular disease, severe constipation, skeletal-related events, liver insufficiency, and respiratory distress are some of the complications of MPPGs (Ayala-Ramirez et al. 2013, Thosani et al. 2015, Roman-Gonzalez et al. 2018, Jasim $\&$ Jimenez 2019). Systemic therapies are limited; in the United States, only high-specific-activity iodine-131 metaiodobenzylguanidine (HSA-I-131-MIBG) has been approved for MPPGs that express the noradrenaline transporter (Pryma et al. 2019).

Up to $50 \%$ of patients with MPPGs carry an inactivating germline mutation of the succinate dehydrogenase subunit B (SDHB) gene (Dahia 2014). These mutations predispose to pseudohypoxia, inflammation, necrosis, abnormal cell proliferation, angiogenesis,
DNA hypermethylation, and epithelial-to-mesenchymal transition (Favier et al. 2015). This molecular phenotype is common to other hereditary and apparently sporadic MPPGs (Dahia et al. 2005). As in many other cancers, pseudohypoxia and angiogenesis could be therapeutic targets. In this review, we focus on angiogenesis as a hallmark of MPPGs, the clinical implications in MPPGs, and the potential benefits of antiangiogenic therapies.

\section{Angiogenesis as a hallmark of cancer}

Development of a metastatic tumor is a complex event that involves several complementary biological capabilities known collectively as the 'hallmarks of cancer'. These hallmarks include abnormal and sustained proliferative signaling, enabling of replicative immortality, genomic instability and mutation, deregulation of cellular energetics, tumor-promoting inflammation, angiogenesis, evasion of growth suppressors, resistance to cell death, activation of invasion and metastasis, and avoidance of immune recognition and destruction (Hanahan \& Weinberg 2011). As the tumor develops, its microenvironment changes; this microenvironment is very complex and dynamic and includes non-cancer cells such as endothelial cells, pericytes, immune inflammatory cells, fibroblasts, and an extracellular matrix that is constantly built and remodeled. The interactions between the cancer and non-cancer cells and the extracellular matrix collectively enable the tumor's growth and spread (Hanahan \& Weinberg 2011).

From the perspective of the hallmarks of cancer, MPPGs have a lower mutation burden and proliferative rates and less inflammation than other malignancies. MPPGs are, however, characterized by a pronounced angiogenesis.

Angiogenesis suggests the formation of new capillaries from previous vessels. Under normal conditions, angiogenesis determines organ growth, wound repair, reproduction, tissue differentiation and communication, and embryonic development. Angiogenesis is tightly regulated by intracellular oxygen tension and a balance between proangiogenic and antiangiogenic factors (Pugh \& Ratcliffe 2003). The endothelial and smooth muscle cells sense oxygen concentrations with use of various mechanisms including endothelial nitric oxide synthase, reduced NAD phosphate (NADPH) oxydases, heme oxygenases, and others. Interactions of oxygen
C) 2020 Society for Endocrinology Published by Bioscientifica Ltd. Printed in Great Britain 
sensors with the family of transcription factors called hypoxia-inducible factor alpha subunit (HIF- $\alpha$ ) determine the cellular adaptation to the oxygen tension. With adequate oxygen concentrations, HIF- $\alpha$ have a short life due to hydroxylation by prolyl hydroxylases and binding to von Hippel-Lindau (VHL) protein that leads to ubiquitination and proteasome degradation. When oxygen concentrations are low, HIF- $\alpha$ are stabilized. In the nuclei, HIF- $\alpha$ transcribe the genes of several proangiogenic and cell growth factors including vascular endothelial growth factors (VEGFs) A, B, C, $\mathrm{D}$, and E; fibroblast, platelet-derived, hepatocyte, and epidermal growth factors; transforming growth factors- $\alpha$ and $\beta$; tumor necrosis factor- $\alpha$ (TNF- $\alpha)$; and others. These factors induce cell replication and angiogenesis. Once the energetic demands are satisfied, antiangiogenic factors are released, preventing additional vascular formation and removing the newly created vessels. Inhibitors of angiogenesis include angiostatin, endostatin, vasostatin, osteopontin, and kininogen domains (Sakurai \& Kudo 2011).

From an oncological perspective, angiogenesis is critical for the development of cancer cells and metastatic colonization (Folkman 1971). Tumor replication requires angiogenesis to supply oxygen and nutrients and eliminate toxic products. Without a blood supply, the tumor cannot develop beyond the limit of diffusion (no more than a few millimeters) and therefore remains small. Due to replication, the new and existing tumor cells lack nutrients and oxygen, stabilizing the HIF- $\alpha$; in the nucleus, the HIF- $\alpha$ bind to hypoxia response elements with downstream transcription of proangiogenic molecules (Pugh \& Ratcliffe 2003). At the same time, antiangiogenic molecules are inhibited, switching the tumor's phenotype from non-angiogenic to angiogenic (Hanahan \& Folkman 1996). VEGFs interact with peritumoral endothelial and cancer cell membrane receptors, activating the MAPK pathway and inducing angiogenesis and tumor progression (Pugh \& Ratcliffe 2003). The new vessels do not look like normal vessels. These vessels are disorganized and enlarged, and their endothelial cells are not well-connected, favoring tumor expansion, vessel invasion, tumor cell separation, and cell spread (Lugano et al. 2020).

Gaining an understanding of tumor hypoxia and angiogenesis has had a huge therapeutic impact in cancer. Antiangiogenic therapies such as axitinib, bevacizumab, cabozantinib, lenvatinib, pazopanib, sorafenib, or sunitinib have been approved treatments for several malignancies (Lugano et al. 2020).

(c) 2020 Society for Endocrinology Published by Bioscientifica Ltd. Printed in Great Britain

\section{Angiogenesis in pheochromocytomas and paragangliomas}

Imaging and surgical descriptions indicate that most pheochromocytomas and paragangliomas are highly vascular tumors. Conventional imaging studies such as CT and MRI frequently describe a rich and complex peritumoral network of vessels, especially in large tumors; furthermore, these tumors are described as bright lesions in MRI T2-weighted sequences (Varghese et al. 1997). Surgical interventions require careful planning and sometimes the support of a vascular surgeon. When compared with resection of adrenal adenomas, resection of pheochromocytomas is more frequently associated with vascular complications, bleeding, blood transfusions, and longer and more expensive hospital admissions (Parikh et al. 2017).

In the early 1990s, murine and human pheochromocytomas were found to express VEGFs (Claffey et al. 1992, Sheehy et al. 1997). In addition, the rat PC12 pheochromocytoma cell metastatic model exhibited peritumoral angiogenesis mediated by VEGFs and inhibited by anti-VEGF antibodies (Middeke et al. 2002). These observations led to the hypothesis that angiogenesis may predict the metastatic potential of pheochromocytoma and paraganglioma and that antagonizing the VEGF pathway may improve clinical outcomes.

Liu et al. correlated the expression of factor VIII/von Willebrand factor antigen with the tumor's microvessel count and density and the presence of capsular/vascular invasion and/or metastases (Liu et al. 1996). The study included 24 pheochromocytomas and 18 paragangliomas. Six tumors had capsular/vascular invasion and four had metastases. The study found that the highest vascular density was in the tumor periphery and that MPPGs and tumors with capsular/vascular invasion had a significantly higher number of blood vessels when compared with tumors without capsular/vascular invasion and metastases. Of interest, there was no difference in vascular content between pheochromocytomas and paragangliomas. The study had limitations; however, the number of samples for analysis was small; there was variability in the number of blood vessels within histologic sections; and the staining for factor VIII/von Willebrand factor antigen likely missed small vessels. Furthermore, the follow-up of these patients was short, and long-term outcomes with regard to metastases and survival were unknown.

Ohji et al. correlated the expression of CD34 with the tumor's microvessel count (Ohji et al. 2001). 
CD34 is a more sensitive endothelial marker than the factor VIII/von Willebrand factor antigen is. The study included 23 pheochromocytomas and 2 paragangliomas. Four patients had metastases. The study confirmed angiogenesis; however, the microvascular counting was not different between MPPGs and tumors without metastases.

Zielke et al. tried to understand the association between angiogenesis and MPPG progression (Zielke et al. 2002). Their study included ten tumors with no metastases, five tumors with capsular/vascular invasion, and five MPPGs. The results indicated that the vascular surface density cannot predict metastatic potential. Nevertheless, concentrations of VEGFs were significantly higher in MPPGs. As in previous studies, the sample for analysis was small.

In a larger study by Salmenkivi et al., the expression of VEGFs was quantified in 69 pheochromocytomas and 36 paragangliomas (Salmenkivi et al. 2003). Their study included control samples of normal adrenal medulla, 60 tumors with no metastases or peritumoral invasion, 37 tumors with capsular/vascular invasion but no metastases, and 8 MPPGs. The study found no expression of VEGFs in normal adrenal medulla cells or in 20 tumors without metastases. Nevertheless, the majority of pheochromocytomas and paragangliomas without distant metastases $(n=77)$ had immunoreactivity for VEGF. There was moderate to high expression of VEGF in several tumors without metastases and in all MPPGs. Other studies have noticed that expression of VEGFR 1-2 is present in pheochromocytomas and paragangliomas but not in the normal adrenal medulla and that levels are, in general, higher in MPPGs than in tumors without metastases (Takekoshi et al. 2004, Ferreira et al. 2014).

The vascular architecture also has been evaluated as a potential predictor of metastases (Favier et al. 2002). In this study, tumors that did not have metastases had short, straight, vascular segments with uniform distribution. Conversely, MPPGs had larger segments of irregular length and displayed at least one branching on open luminal space. Expression of proangiogenic factors such as EPAS1, VEGF, VEGFR1-2, and endothelin receptors $A$ (ETA) and $B$ (ETB) was more obvious in MPPGs; ETA in pericytes and tumoral cells and ETB in endothelial cells discriminated between tumors with and without metastases (Favier et al. 2002, Oudijk et al. 2015). However, the sensitivity and specificity rates of the irregular vascular architecture as a predictor of metastases were only $59.7 \%$ and $72.9 \%$, respectively; therefore, an abnormal vascular architecture cannot be used as a single predictor of metastases (Białas et al. 2014, Oudijk et al. 2015).

CD31 and CD105 are sensitive endothelial markers with high expression in the central areas of MPPGs where oxygen tension is expected to be low. The evaluation of these markers did not find differences in vascular density between MPPGs and tumors without metastases (Białas et al. 2014). Vascular density cannot be considered a strong predictor of metastases (Rooijens et al. 2004). Together, these studies indicate that pheochromocytomas and paragangliomas exhibit increased and abnormal angiogenesis that is, in part, mediated by the VEGF pathway; however, angiogenesis per se cannot be used to predict the metastatic potential of these tumors. None of these studies correlated angiogenesis with the tumor's genetic background.

Angiogenesis is influenced by the genetic background. Mutations of the $S D H B$ gene are prevalent in patients with MPPGs. SDHB codifies for the subunit B of the mitochondrial enzymatic complex 2 or succinate dehydrogenase. This enzymatic complex allows for the conversion of succinate into fumarate in the citric acid cycle and for the transport of electrons through the internal mitochondrial membrane (Mannelli et al. 2015). Thus, succinate dehydrogenase is a regulator of the cellular metabolism of oxygen. Inactivating mutations of $S D H B$ leads to pseudohypoxia and accumulation of succinate (Gimenez-Roqueplo et al. 2002); succinate inhibits prolyl hydroxylases, stabilizing HIF- $\alpha$ and triggering abnormal cell growth and angiogenesis (Favier \& GimenezRoqueplo 2010). In fact, SDHB pheochromocytomas and paragangliomas are frequently large, highly vascular tumors that express high concentrations of VEGFs, PDGF, endothelin, and angiopoietin (GimenezRoqueplo et al. 2002). Of interest, inactivating mutations in the genes that code for the subunits A, C, D, and the co-factor SDHAF2 of succinate dehydrogenase also cause pseudohypoxia and angiogenesis (Favier et al. 2002, 2012). This molecular phenotype is shared with VHL-related pheochromocytomas and paragangliomas and a substantial number of sporadic tumors (cluster 1) (Takekoshi et al. 2004, Favier \& Gimenez-Roqueplo 2010, Favier et al. 2012, 2015). Cluster 1 tumors with and without metastases exhibit similar levels of VEGF and other proangiogenic factors. Angiogenesis cannot predict the cluster 1 metastatic potential. In fact, most tumors associated with SDHA, SDHC, SDHD, and VHL mutations are not metastatic.

Cluster 2 pheochromocytomas and paragangliomas are associated with activating mutations of the RET (c) 2020 Society for Endocrinology Published by Bioscientifica Ltd. Printed in Great Britain 
proto-oncogene or inactivating mutations of the neurofibromatosis type 1 (NF1), MAX, HRAS, MET, FGFR1, or TMEM127 genes (Crona et al. 2013, CastroVega et al. 2015, Toledo et al. 2016, Fishbein et al. 2017). Although cluster 2 tumors are not characterized by a cellular environment of pseudohypoxia and their expression of VEGFs is lower than that in cluster 1 tumors, cluster 2 tumors exhibit angiogenesis (Santoro et al. 2002). RET, NF1, and RAS mutations upregulate HIF- $\alpha$ through activation of extracellular signal regulated kinase (ERK) in the MAPK pathway (Richard et al. 1999, Lim et al. 2004). ERK phosphorylates HIF-1 $\alpha$, inducing angiogenesis and tumor growth. TMEM127 and MAX seem to upregulate HIF- $\alpha$ through activation of the mTOR pathway; however, the details of this mechanism are unclear (Brugarolas et al. 2004, Land \& Tee 2007). Cluster 2 MPPGs seem to have higher concentrations of VEGFs compared with levels in tumors without metastases (Favier et al. 2012). Recently, the TCGA identified a third cluster of pheochromocytomas and paragangliomas (Fishbein et al. 2017). This cluster represents $\sim 5 \%$ of these tumors and is associated with Wnt pathway abnormalities. These tumors may have a metastatic phenotype. The mechanism of angiogenesis in these tumors is currently unknown.

Several other biomarkers associated with a high risk of metastases, regardless of tumor SDHB status, have been identified. These biomarkers include somatic mutations of ATRX and telomerase reverse transcriptase (TERT), high TERT expression, and miRNA cluster 182/96/183, miR-210, and miR-483 (Calsina et al. 2019, Goncalves et al. 2019, Job et al. 2019, Dahia et al. 2020). Of interest, some of these biomarkers promote angiogenesis. For example, aberrant expression of TERT, in addition to causing tumor immortalization, increases expression of VEGFs by interacting with transcription factor Sp1 (Liu et al. 2016); also, miR-210 is involved in vascular remodeling in the tumor microenvironment (Jung et al. 2017).

\section{Antiangiogenic therapy for MPPGs}

Axitinib, cabozantinib, lenvatinib, pazopanib, and sunitinib are antiangiogenic medications currently being evaluated in clinical trials for patients with MPPGs. These medications inhibit multiple tyrosine kinase receptors involved in angiogenesis, tumor growth, invasiveness, and the development of metastases (Table 1). Used as antiangiogenic therapies, they prevent activation of the VEGF pathway, leading to vascular depletion, normalization of the tumor vascular network, and enhanced recognition of tumor cells by the immune system (Fig. 1) (Shrimali et al. 2010, Carmeliet \& Jain 2011, Goel et al. 2011, Lugano et al. 2020). Since we do not have reliable models of human MPPGs, the physiological effects of antiangiogenic therapies are discussed by extrapolating information derived from important basic, translational, and clinical studies in other vascular malignancies treated with these drugs. However, we recognize that the actions of antiangiogenic therapies in MPPGs may be somewhat different or even unique compared with these actions in other cancers or among clusters/subtypes of MPPGs.

Vascular depletion decreases the supply of oxygen and nutrients to cancer cells, leading to their death. Normalization of the tumor vascular network suggests restoration of the normal structure and function of the tumor vessels. Thus, the tumor vessels' diameter decreases; adhesion of endothelial cells increases, limiting vascular permeability; and delivery of oxygen to the tumor cells increases, decreasing the rate of tumor growth and spread. Furthermore, normalization of the vasculature may facilitate the delivery of concomitant therapies such as radiotherapy, chemotherapy, and/or immunotherapy (Fig. 1). This has been demonstrated in mouse models of several cancers other than MPPGs and may explain the significantly longer progressionfree survival (PFS) rates observed in some cancer patients treated with a combination of antiangiogenic drugs and

Table 1 Targets and affinity of tyrosine kinase receptor inhibitors currently being evaluated in metastatic pheochromocytoma and paraganglioma.

\begin{tabular}{|c|c|c|c|c|c|c|c|}
\hline \multirow[b]{2}{*}{ Drug } & \multicolumn{7}{|c|}{ IC50 (nm) } \\
\hline & VEGFR-1 & VEGFR-2 & VEGFR-3 & PDGFR- $\beta$ & RET & c-MET & FGFR1 \\
\hline Axitinib & 1.2 & 0.25 & 0.29 & 1.6 & - & - & - \\
\hline Cabozantinib & - & 0.035 & - & - & 4 & 1.3 & - \\
\hline Lenvatinib & 22 & 4 & 5.2 & 39 & - & - & 46 \\
\hline Pazopanib & 10 & 30 & 47 & 84 & - & - & 74 \\
\hline Sunitinib & 2 & 9 & 17 & 2 & 41 & 4000 & \\
\hline
\end{tabular}




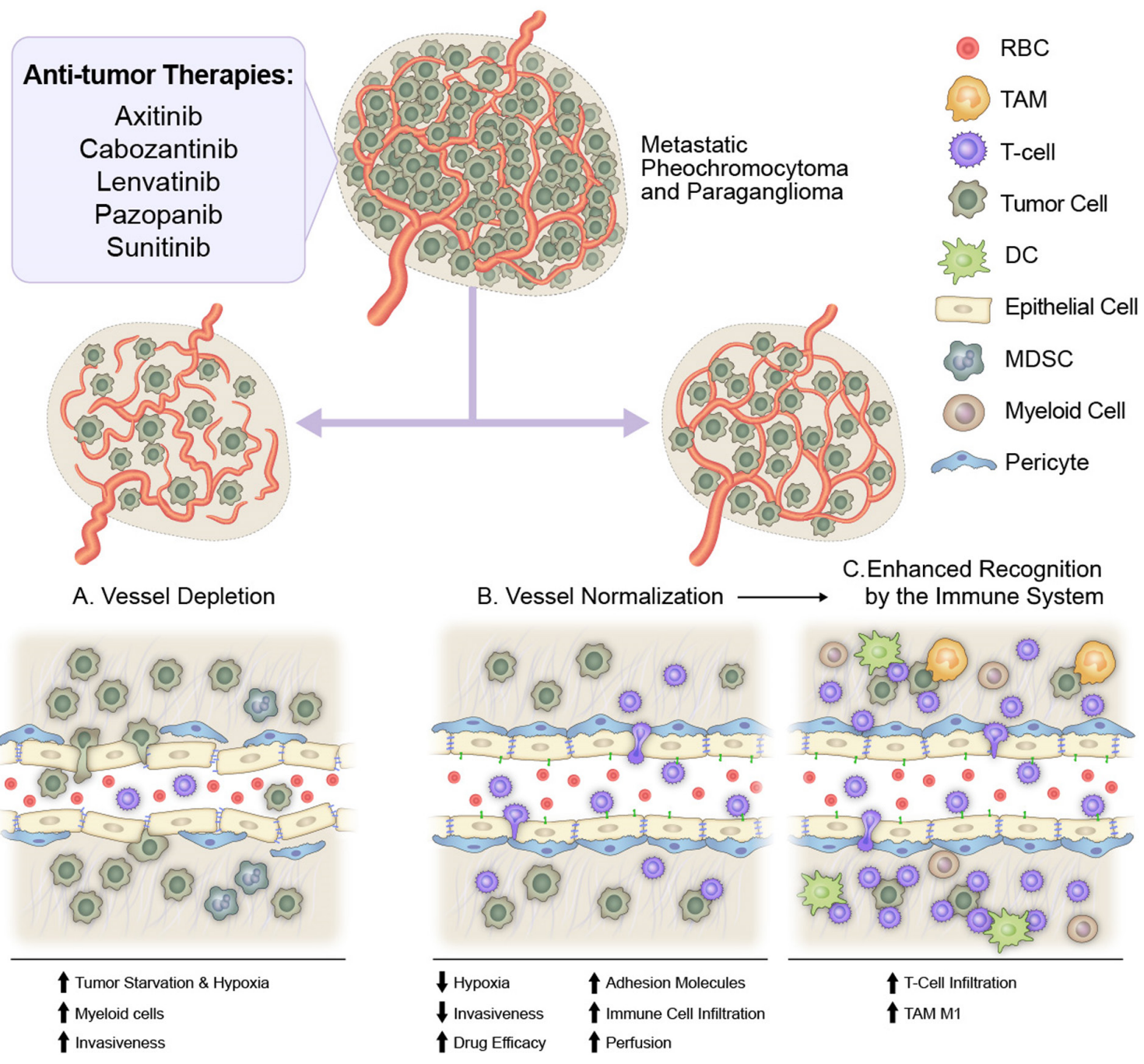

Figure 1

Vascular consequences of anti-angiogenic therapy. Antiangiogenic therapy may lead to (A) vessel depletion and (B) normalization of tumor vascular network with enhanced recognition by the immune system. The consequences of these effects and their therapeutic implications are different. RBC: red blood cells; TAM: tumor-associated macrophages; DC: dendritic cells; MDSC: myeloid derived suppressor cells.

chemotherapy compared with rates associated with use of chemotherapy alone (Mazzone et al. 2009, Jayson et al. 2012). However, normalization of the tumor vascular function may not happen in every cancer treated with antiangiogenic therapy. In patients with glioblastoma, for example, bevacizumab induces morphological vascular normalization, but vascular function is not improved; this lack of functional improvement leads to decreased tumor blood flow, hypoxia, tumor growth and invasion, and no benefit in survivorship (Obad et al. 2018). Whether morphological and functional vascular normalization could happen in MPPGs treated with antiangiogenic therapy still needs to be determined.

Regarding tumor angiogenesis and its impact on the immune system, overexposure to angiogenic factors decreases expression of endothelial cells' adhesion molecules, impairing the activation of inflammatory pathways mediated by factors such as interleukin-1, TNF- $\alpha$, and others that would otherwise lead to immune system recognition (Griffioen et al. 1996); furthermore, the activation of the VEGF prevents dendritic cell maturation (antigen presenting cells), discourages T cell-infiltration, and promotes the activation of regulatory $\mathrm{T}$ cells that also prevent the recognition of the cancer cells by the immune system (Manegold et al. 2017); this mechanism perhaps explains, at least in part, why the cells of vascular tumors are not recognized by the immune system. The vascular normalization that follows antiangiogenic therapy may increase the expression of adhesion molecules that attract cytotoxic $\mathrm{T}$ cells and decrease the presence of Printed in Great Britain 
immune-suppressive T cells (Fig. 1) (Shrimali et al. 2010). In addition to the antiangiogenic properties of this therapy, blockage of the VEGF pathway, together with inhibition of other tyrosine kinase receptors, such as fibroblast growth factors (lenvatinib) or c-met receptors (cabozantinib), may prevent tumor cell replication and/or tumor invasiveness and metastases (Trusolino et al. 2010). As such, these drugs target multiple fronts and are promising therapies for patients with MPPGs.

These drugs have been tested in phase 1,2 , and 3 clinical trials for malignancies other than MPPGs. Subsequently, their pharmacokinetics, pharmacodynamics, oncological benefits, and safety profile have been, in general, wellcharacterized (Tables 1 and 2). Nevertheless, their impact on MPPGs is for most part still to be determined. The following is a discussion of the potential benefits and adverse effects of these medications in patients with MPPGs based on clinical observations derived from case reports, retrospective studies, and clinical trials (Table 3). The descriptions follow the historical order of drug discovery.

\section{Sunitinib}

Sunitinib inhibits VEGFRs 1-3, PDGFRs, RET, FLT3, and Kit. receptors. The drug is approved for the treatment of clear cell renal cell carcinoma, pancreatic neuroendocrine tumors, and gastrointestinal stromal tumors. Sunitinib is prescribed in cycles of $50 \mathrm{mg}$ daily for 4 weeks followed by a 2-week rest period. Sunitinib is the first antiangiogenic medication recognized as a potential treatment for MPPGs.

Preclinical studies with sunitinib in a PC12 xenograft mouse model demonstrated potent antiangiogenic activity. Inhibition of VEGFRs by sunitinib prevented blood vessel sprouting and decreased the number and extension of the tumor microvessels; furthermore, sunitinib caused apoptosis in the PC12 cells (Saito et al. 2012, Denorme et al. 2014). PC12 apoptosis was mediated by inactivation of antiapoptotic molecule Bcl-2 and activation of the proapoptotic molecule BAD (Saito et al. 2012). Inhibition of angiogenesis and tumor apoptosis led to a dramatic reduction in tumor size (Denorme et al. 2014). However, abrupt interruption of sunitinib led to rapid regrowth of the tumor and its vessels; this finding suggested that treatment with sunitinib must be continuous in order to preserve its therapeutic effect (Denorme et al. 2014). Of interest, in PC12 cells, the inhibition of VEGFR-2 by sunitinib decreased the activity of tyrosine hydroxylase, reducing the synthesis of catecholamines (Aita et al. 2012).

A recent, elegant study in a murine model of $S D H B$-/paraganglioma combined three imaging modalities to explore the effects of sunitinib on tumor proliferation (CT), angiogenesis (Ultrafast Doppler ultrasound), and glucose metabolism (FDG-PET) (Facchin et al. 2020). The study noted that all mice treated with sunitinib had a decreased tumor size and glucose uptake, with some reduction in the length and volume of the tumor vessels - the effect of sunitinib in the tumor capillaries and other small vessels was not evaluable due to technical limitations. The effects of sunitinib on these three hallmarks were transitory and the tumor later developed resistance that inversely correlated with the inhibitory effects on the tumor vessels length and glycolysis. The results of this study suggested that metabolic symbiosis is a mechanism of resistance to sunitinib (discussed later). The study raised interesting questions on the use of complementary imaging studies in humans to better understand the actions of antiangiogenic medications. In addition, it suggested exploring therapeutic combinations (e.g. antiangiogenic therapies and antimetabolites) to delay/prevent tumor resistance.

One of the original reports in humans described the effects of sunitinib in a VHL patient with bilateral kidney cancers, multiple pancreatic neuroendocrine tumors, and a metastatic sympathetic paraganglioma with high expression of VEGF and PDGFR- $\beta$ (Jimenez et al. 2009). The presence of angiogenesis in the paraganglioma and the multifocal kidney cancer supported the use of sunitinib. The patient exhibited impressive partial responses (PRs) in all tumors, improvement of hypertension, relief of pain related to bone metastases, and disease stabilization for some time. This study supported the development of a

Table 2 Pharmacokinetic properties of antiangiogenic therapies for MPPGs.

\begin{tabular}{lll}
\hline Drug & & Bioavailability \\
\cline { 1 - 1 } Axitinib & & $58 \%$ \\
Cabozantinib & Unknown \\
Lenvatinib & & $85 \%$ \\
Pazopanib & & $14-39 \%$ \\
Sunitinib & Unknown \\
\hline
\end{tabular}

https://erc.bioscientifica.com

https://doi.org/10.1530/ERC-20-0043

\begin{tabular}{c}
\hline Peak serum (hours) \\
\hline $2.5-4$ \\
$2-5$ \\
$1-4$ \\
$2-4$ \\
$6-12$ \\
\hline
\end{tabular}

\begin{tabular}{c}
\hline Protein binding \\
\hline$>99 \%$ \\
$99.7 \%$ \\
$98-99 \%$ \\
$>99 \%$ \\
$95 \%$ \\
\hline
\end{tabular}

\begin{tabular}{l} 
Hepatic metabolism \\
\hline CYP3A4 \\
CYP3A4 \\
CYP3A4 \\
CYP3A4 \\
CYP3A4
\end{tabular}

Excretion

Feces 41\%, Urine 23\% Feces 54\%, Urine 27\% Feces 65\%, Urine 25\% Feces $>90 \%$, Urine $<4 \%$ Feces $61 \%$, Urine 16\% (c) 2020 Society for Endocrinology Published by Bioscientifica Ltd. Printed in Great Britain 
Table 3 Clinical trials of anti-angiogenic therapies in pheochromocytoma and paraganglioma.

\begin{tabular}{|c|c|c|c|c|c|c|c|}
\hline Drug & $\begin{array}{l}\text { Clinical trial } \\
\text { identifier }\end{array}$ & Main center & $\begin{array}{l}\text { Primary } \\
\text { outcome }\end{array}$ & Translational studies & $n$ & Design & $\begin{array}{l}\text { Status on } \\
\text { ClinicalTrial.gov }\end{array}$ \\
\hline Axitinib & NCT03839498 & $\begin{array}{l}\text { Columbia } \\
\text { University }\end{array}$ & $\begin{array}{l}\text { Objective } \\
\text { response } \\
\text { rate }\end{array}$ & $\begin{array}{l}\text { Activation of VEGFR } \\
\text { pathway and } \\
\text { relationship with } \\
\text { response to therapy. }\end{array}$ & 25 & $\begin{array}{l}\text { Single group } \\
\text { assignment }\end{array}$ & Recruiting \\
\hline Axitinib & NCT01967576 & $\begin{array}{l}\text { National } \\
\text { Cancer } \\
\text { Institute }\end{array}$ & $\begin{array}{l}\text { Objective } \\
\text { response } \\
\text { rate }\end{array}$ & $\begin{array}{l}\text { VEGFR in blood. } \\
\text { Activation of VEGFR } \\
\text { pathway and } \\
\text { relationship with } \\
\text { response to therapy. }\end{array}$ & 14 & $\begin{array}{l}\text { Single group } \\
\text { assignment }\end{array}$ & $\begin{array}{l}\text { Active, not } \\
\text { recruiting }\end{array}$ \\
\hline Cabozantinibab & NCT02302833 & $\begin{array}{l}\text { MD } \\
\text { Anderson } \\
\text { Cancer } \\
\text { Center }\end{array}$ & $\begin{array}{l}\text { Objective } \\
\text { response } \\
\text { rate }\end{array}$ & $\begin{array}{l}\text { c-MET expression and } \\
\text { relationship with } \\
\text { prognosis and } \\
\text { response to therapy } \\
\text { Correlation between } \\
\text { tumor response and } \\
\text { germline/somatic } \\
\text { mutational status. }\end{array}$ & 22 & $\begin{array}{l}\text { Single group } \\
\text { assignment }\end{array}$ & Recruiting \\
\hline Lenvatinib & NCT03008369 & Mayo Clinic & $\begin{array}{l}\text { Objective } \\
\text { response } \\
\text { rate }\end{array}$ & $\begin{array}{l}\text { Correlation between } \\
\text { tumor response and } \\
\text { germline/somatic } \\
\text { mutational status }\end{array}$ & 3 & $\begin{array}{l}\text { Single group } \\
\text { assignment }\end{array}$ & $\begin{array}{l}\text { Active, not } \\
\text { recruiting }\end{array}$ \\
\hline Pazopanib & NCT01340794 & Mayo Clinic & $\begin{array}{l}\text { Objective } \\
\text { response } \\
\text { rate }\end{array}$ & $\begin{array}{l}\text { Correlation between } \\
\text { tumor response and } \\
\text { germline/somatic } \\
\text { mutational status. } \\
\text { Association of tumor } \\
\text { response and } \\
\text { expression of HIF-1 } \alpha, \\
\text { VEGFR and microvessel } \\
\text { density }\end{array}$ & 7 & $\begin{array}{l}\text { Single group } \\
\text { assignment }\end{array}$ & $\begin{array}{l}\text { Terminated (slow } \\
\text { accrual) } \\
\text { Results published }\end{array}$ \\
\hline Sunitinibac & NCT01371201 & $\begin{array}{l}\text { Gustave } \\
\text { Roussy }\end{array}$ & $\begin{array}{r}\text { PFS at } 12 \\
\text { months }\end{array}$ & $\begin{array}{l}\text { Effect on markers of } \\
\text { biochemical activity }\end{array}$ & 74 & $\begin{array}{l}\text { Parallel } \\
\text { assignment }\end{array}$ & Recruiting \\
\hline Sunitinib & NCT00843037 & $\begin{array}{l}\text { University } \\
\text { Health } \\
\text { Network }\end{array}$ & $\begin{array}{l}\text { Clinical } \\
\text { benefit } \\
\text { rate }\end{array}$ & $\begin{array}{l}\text { Predictors of response } \\
\text { and surrogate markers } \\
\text { of survival }\end{array}$ & 25 & $\begin{array}{l}\text { Single group } \\
\text { assignment }\end{array}$ & $\begin{array}{l}\text { Active, not } \\
\text { recruiting. } \\
\text { Results published }\end{array}$ \\
\hline
\end{tabular}

Some trials were prematurely terminated due to low accrual and/or severe side effects such as hypertension.

aThese are perhaps the most promising clinical trials: abPreliminary results show DCR = 92\%; acThe primary outcome of this trial is PFS at 12 months and it has a design that allows comparisons.

phase 2 trial for patients with VHL (Jonasch et al. 2011). This trial excluded patients with MPPGs because of safety concerns for blood pressure control.

In another report, sunitinib was discovered to be a potential treatment after it was prescribed to a patient with a nonresectable peri-renal paraganglioma that had been confused with kidney cancer (Joshua et al. 2009). The tumor decreased in size, which made its removal possible and later confirmed the diagnosis of paraganglioma. Two other patients with MPPGs were subsequently treated with sunitinib and achieved good oncological responses. One patient's tumor was biopsied 18 weeks after treatment; histological analysis revealed decreased expression of VEGFRs, and the patient responded to sunitinib for at least 40 weeks. Unfortunately, no other studies have reported posttreatment biopsies; therefore, the ways in which antiangiogenic medications affect MPPGs' histology, vascular physiology, and microenvironment are unknown.

A retrospective intention-to-treat study of 17 patients treated with sunitinib showed clinical benefits in $47 \%$ of patients, including 3 patients who had a PR, disease stabilization for more than 2 years in some cases, normalization of hypertension, and discontinuation of antihypertensive medications in a few patients (AyalaRamirez et al. 2012). There were no complete responses (CRs). Patients with clinical benefits had tumors associated with SDHB mutations as well as apparently sporadic MPPGs; some of these patients had previously received chemotherapy or had been treated with I-131-MIBG.
2020 Society for Endocrinology Published by Bioscientifica Ltd. Printed in Great Britain 
The study showed a median PFS of 4.1 months and concluded that sunitinib may offer clinical benefits to some patients with MPPGs, irrespective of their genetic background. Nevertheless, adverse events due to excessive release of catecholamines because of tumor destruction as well as direct sunitinib-associated toxicity such as hypertension may prevent successful treatment. Therefore, patients with MPPGs treated with antiangiogenic medications must be treated with alpha- and beta-blockers and frequently with other antihypertensives before and during therapy; furthermore, supportive measures to prevent or treat adverse events directly related to the drug had to be implemented (i.e. moisturizers and hand and feet rest to prevent erythrodysesthesia and analgesic therapy to ameliorate or prevent pain exacerbation during tumor destruction). The study also suggested that a dose lower than $50 \mathrm{mg}$ daily may provide clinical benefits with fewer adverse effects. As described in other cancers, tumor resistance was possible.

Bone metastases are quite common in patients with MPPGs (Ayala-Ramirez et al. 2013). In this retrospective study, patients with predominant bone metastases had a substantial reduction of glucose uptake in their FDG-PET scans (Ayala-Ramirez et al. 2012). A subsequent report suggested that sunitinib may decrease the rate of skeletal-associated events (Ayala-Ramirez et al. 2013).

A phase 2 clinical trial with sunitinib at $50 \mathrm{mg}$ daily, 4 weeks on and 2 weeks off, was subsequently developed (SNIPP, NCT00843037) (O'Kane et al. 2019). The primary end point was disease control rate (DCR) at 12 weeks. The study included 23 patients with MPPGs and 2 patients with unresectable primary tumors without metastases. Three patients (13\%) achieved PR, and 16 (70\%) had stable disease (SD). Six patients with SD had tumor regression (12-27\%). No patients had CR. The DCR was $83 \%$ (95\% CI: 56-93\%). PFS was 13.4 months (95\% CI: 5.3-24.6 months). The most common adverse events ( $>60 \%$ of patients) were grade $1-2$ fatigue, nausea/ vomiting, and palmar-plantar erythrodysesthesia. Fiftysix percent of patients experienced grade 3 adverse events and 12\% experienced grade 4 adverse events. Two patients had grade 3 or 4 hypertension. Several patients required dose reduction, and $20 \%$ of patients discontinued sunitinib because of adverse events including severe hypertension, myocardial infarction, and restrictive cardiomyopathy. The three patients with PR had hereditary MPPGs associated with SDHA, SDHB, and RET mutations, respectively. The patient with multiple endocrine neoplasia type 2 (MEN2) had the most impressive response, with a tumor size reduction of $64 \%$ and stabilization for longer than 7 years. MEN2MPPGs are quite rare (Thosani et al. 2013). Simultaneous inhibition of the RET and VEGF receptors may have led to this impressive response.

The SNIPP study showed that sunitinib benefits most patients with MPPGs. However, its antineoplastic actions are modest, with a low objective response rate (ORR). In addition, toxic effects with standard doses could be substantial and tumor resistance develops over time. Nevertheless, when compared with the PFS rates observed in clinical trials for patients with kidney cancer or pancreatic neuroendocrine tumors, the median duration of response in patients with MPPGs was actually good (11, 12, and 13.4 months, respectively) (Motzer et al. 2007, Faivre et al. 2017).

A phase 2 clinical trial comparing sunitinib at $37.5 \mathrm{mg}$ daily vs placebo is ongoing (FIRSTMAPPP, NCT01371201) and may be able to provide survivorship data.

\section{Pazopanib}

Pazopanib inhibits VEGFRs 1-3, PDGFRs, c-FMS, and Kit receptors. The drug is approved for treatment of clear cell renal cell carcinoma and soft tissue sarcomas at a dose of $800 \mathrm{mg}$ daily. Pazopanib became a drug of interest because its antiangiogenic mechanisms overlap with those of sunitinib, but its toxic effects can be milder than those of sunitinib (Motzer et al. 2013). In a phase 2 clinical trial with pazopanib (NCT1340794) (Jasim et al. 2017), the primary end point was ORR. Pazopanib was provided at a starting dose of $400 \mathrm{mg}$ daily to test patients' tolerability. Two weeks later, the dose was increased to $800 \mathrm{mg}$ daily. The trial included six evaluable patients. One patient achieved a PR that lasted for longer than 24 months. There were no CRs. Median PFS was 6.5 months. Substantial cardiovascular toxicity was noticed, especially when the dose of pazopanib was doubled. Half the patients had severe hypertension; two developed catecholamineinduced cardiomyopathy and had to discontinue trial participation. The trial was terminated due to low accrual.

\section{Axitinib}

Axitinib inhibits VEGFRs $1-3$ and the PDGFR- $\beta$. Axitinib was approved for treatment of clear cell renal cell carcinoma at a starting dose of $5 \mathrm{mg}$ twice daily; this dose is increased to 7 or $10 \mathrm{mg}$ twice daily as long as the patient's blood pressure remains lower than 150/90 $\mathrm{mmHg}$ (Rini et al. 2013). The antineoplastic effects in patients with clear cell 
renal cell carcinoma are more obvious with doses higher than $5 \mathrm{mg}$ twice daily.

Axitinib is a more potent antiangiogenic medication than are pazopanib and sunitinib. In addition, axitinib does not inhibit c-Kit or FLT3 receptors and may be easier to tolerate. However, axitinib frequently causes severe hypertension (van Geel et al. 2012) A phase 2 clinical trial with axitinib for patients with progressive MPPGs was developed (NCT01967576) (Burotto Pichun et al. 2015). The primary end point was ORR. The trial recruited 14 patients. Preliminary results derived from 11 patients showed 4 patients with a PR (36\%) and 6 with SD (55\%), including two individuals with some degree of regression (16-18\% reduction); only one patient did not respond to therapy. There were no CRs. Among study patients, $82 \%$ developed severe hypertension and none tolerated a dose of axitinib $\geq 5 \mathrm{mg}$ twice daily. The trial is active but closed to recruitment.

\section{Cabozantinib}

Cabozantinib inhibits VEGFR-2, and the RET and c-MET receptors. The drug is approved for treatment of medullary thyroid, clear cell renal cell, and hepatocellular carcinomas. Several aspects support the evaluation of cabozantinib for patients with MPPGs. Cabozantinib is the most potent antiangiogenic drug available in clinical practice (Table 1). Inhibition of the c-MET pathway could be of interest in patients with MPPGs because activating somatic mutations of the c-MET receptor have been described in these tumors and the pathway activity is enhanced by pseudohypoxia through HIF-1 $\alpha$ stabilization; in addition, VHL protein inactivation increases the activation of C-met (Trusolino et al. 2010, Gherardi et al. 2012, Toledo 2017, Pozas et al. 2019).

Activation of the c-MET pathway contributes to cancer invasiveness, metastases, and escape from apoptosis. Furthermore, the c-MET pathway is upregulated in response to the blockage of the VEGF pathway, leading to the emergence of tumor resistance (Trusolino et al. 2010). Cabozantinib may prevent tumor resistance and metastases. In fact, cabozantinib has been associated with more impressive oncological and durable responses in patients with clear cell renal cell carcinoma than has sunitinib (Choueiri et al. 2017). Cabozantinib is also a more potent inhibitor of the RET receptor than sunitinib is and could be an effective treatment for the rare MEN2-MPPGs (Table 1).

Finally, cabozantinib improves clinical outcomes in patients with cancer and bone metastases (Smith et al. 2016); thus, cabozantinib should be explored in patients with MPPGs and bone lesions. A phase 2 clinical trial with cabozantinib for patients with MPPGs is currently active (NCT02302833) (Jimenez et al. 2017). This trial allows participation of patients with bone metastases. The primary end point is ORR. Patients are treated with cabozantinib at $60 \mathrm{mg}$ daily, and the dose is reduced to 40 or $20 \mathrm{mg}$ daily depending on patients' tolerability. The clinical trial has recruited 17 patients. Preliminary results derived from 11 patients identified 4 patients with PR (37\%) and 6 patients with SD (55\%); all patients with SD had tumor regression (18-29\%). The DCR was 92\%. PFS was 16 months (range, 0.9-36 months). One patient did not respond to therapy. Responders included patients with apparently sporadic MPPGs as well as carriers of $S D H B$ mutations. Unlike the previously described trials, patients treated with cabozantinib have not experienced severe hypertension or cardiovascular events and no patients have discontinued trial participation. The trial is currently recruiting patients.

\section{Lenvatinib}

Lenvatinib inhibits VEGFR 1-3, PDGFR- $\beta$, and FGFR1 (Zschäbitz \& Grüllich 2018). The drug is approved for treatment of follicular origin thyroid, clear cell renal cell, and hepatocellular carcinomas (Hao \& Wang 2020). Lenvatinib has been associated with impressive ORR in these tumors. However, hypertension has been reported as a common and frequently severe adverse event. A patient with a MPPG associated with a mutation of the $S D H B$ gene who was treated with lenvatinib had a rapid and impressive radiographic response (Jasim et al. 2016). A phase 2 clinical trial with lenvatinib has been proposed (NCT03008369) with ORR as the primary end point. The trial is active and has recruited three patients, but recently stopped recruitment. No results have been reported.

\section{Important aspects to consider when developing clinical trials with antiangiogenic drugs}

\section{Pharmacokinetics}

Most antiangiogenics are oral medications with predominant liver metabolism through the cytochrome P450 3A4 (CYP3A4) enzyme (Table 2); thus, drug interactions are possible (www.drugs.com).
C) 2020 Society for Endocrinology Published by Bioscientifica Ltd. Printed in Great Britain 
For instance, grapefruit consumption increases the levels of antiangiogenic drugs and must be avoided. The use of antiangiogenics along with diltiazem, amiodarone, and some beta-blockers must be reviewed with specialists in pharmacology and cardiology, since some interactions may increase the risk of cardiovascular toxicity. The concomitant use of bisphosphonates for bone metastases may increase the risk of osteonecrosis of the jaw. Strict dental hygiene is recommended.

Results of clinical trials with antiangiogenic therapy for MPPGs show that clinical responses, tolerability, and toxicity vary among patients. In addition to drug interactions and the presence of co-morbidity (i.e. liver failure), genetic aspects such as CYP3A4 polymorphisms may contribute to variability in response to anticancer drugs (Preissner et al. 2013). Currently, pharmacological researchers are looking for tests that can assess CYP3A activity to predict doses, improve clinical outcomes, and/or reduce the intensity and frequency of adverse events (Diekstra et al. 2014, García-Donas et al. 2016).

\section{Cardiovascular toxicity}

Clinical trials with antiangiogenic drugs for MPPG have encountered cardiovascular problems, patients have frequently discontinued trial participation, and trial success has been compromised (Jimenez 2018, Jasim \& Jimenez 2019). Preliminary results from a phase 2 trial with cabozantinib have shown no severe cardiovascular events. Patients with MPPGs are very different from those with other cancers for which antiangiogenic drugs are approved, for several reasons: (1) MPPGs release catecholamines, whereas other types of tumors do not; (2) patients' tumor burden is frequently heavier than that in other malignancies; and (3) clinical experience with MPPGs is limited. Patients treated with antiangiogenic medications must be well prepared with antihypertensive medications and carefully monitored by clinicians with experience in catecholamine toxicity. Hormonal behavior is not predictable, and antihypertensives may need frequent and aggressive adjustments. In addition, the dose of the antiangiogenic drug must be carefully chosen. To date, the trial with cabozantinib suggests that small doses may bring oncological benefits with no major cardiovascular toxicity.

\section{Tumor resistance}

Preliminary results indicate that antiangiogenic medications do not cure MPPGs. However, the medications offer antineoplastic effects and stop tumor progression for some time. Resistance at the outset of antiangiogenic therapy is rare (intrinsic resistance); in fact, results of clinical trials with axitinib, cabozantinib, and sunitinib describe an elevated DCR. The mechanisms of intrinsic resistance in the rare cases that do not respond are unknown. Acquired resistance happens in most patients and becomes apparent months to years after initiation of treatment. Mechanisms of acquired resistance include the following: (1) activation of proangiogenic signaling pathways that are not induced by inhibition of the VEGF pathway, (2) subsequent recruitment of endothelial progenitors from bone marrow that are resistant to current tyrosine kinase inhibitors and that release proangiogenic factors that build new vessels, (3) utilization of normal tissue vessels in close proximity to the tumor cells as a supply of oxygen and nutrients (vessel co-option), (4) transformation of tumor cells into endothelial-like cells (vascular mimicry), (5) vascular depletion due to high antiangiogenic drug concentrations that increase hypoxia, promoting tumor progression and spread, (6) activation of pathways that lead to tumor spread (c-met pathway), and (7) tumor symbiosis mediated by overactivation of mammalian target of rapamycin (mTOR) signaling (Bergers \& Hanahan 2008, Zarrin et al. 2017). There are no reliable models of MPPGs, and the evaluation of these mechanisms of resistance is very difficult (LusseyLepoutre et al. 2018). However, final results from some of the phase 2 trials may provide some clues. For instance, the cabozantinib trial does not use maximal doses; this trial may favor the antiangiogenic therapeutic effect of vascular normalization instead of vascular depletion.

\section{Therapeutic combinations}

Antiangiogenic effects may favor other systemic therapies. HSA-I-131-MIBG was recently approved in the United States for the treatment of patients with MPPGs, and Lu-177-DOTATATE is currently being evaluated in clinical trials (NCT03206060 and NCT04106843). These drugs release lethal radioactivity to MPPGs. The vascular normalization caused by antiangiogenic medications may facilitate the radiopharmaceuticals approach to these tumors by enhancing the release of radioactivity. A recent report described a patient treated with a combination of sunitinib and I-131-MIBG who achieved CR for some time (Makis et al. 2016).

Immunotherapy is revolutionizing the oncology world. Immunotherapy has changed clinical outcomes in many patients. For instance, some patients with 
melanoma are now cured with immunotherapy. However, immunotherapy does not work in every cancer. The combination of antiangiogenic drugs with immunotherapy is exciting (Motzer et al. 2019). Targeting the VEGF pathway enhances the efficacy of immunotherapy (Taylor et al. 2020). Vascular normalization activates adhesion molecules and chemokines that recruit and attract cytotoxic $\mathrm{T}$ cells; furthermore, vascular normalization facilitates immune cell mobilization. Many trials combining checkpoint inhibitors and antiangiogenic drugs to treat various malignancies are active; these trials aim to provide a tumor microenvironment that facilitates immune recognition and subsequent attack of cancer cells.

Cluster 1 tumors overexpress the mTOR pathway, and activation of mTOR signaling may lead to tumor symbiosis and resistance to antiangiogenic therapy (Allen et al. 2016, Oudijk et al. 2017). Everolimus, an mTOR inhibitor, was evaluated as single therapy in a clinical trial for patients with MPPGs; results from this trial indicated that everolimus alone was not an effective drug (Oh et al. 2012). However, combining antiangiogenic medications with mTOR inhibitors may lead to more effective and prolonged responses. This has been suggested by a case report of a patient with an MPPG treated with sunitinib and sirolimus (AyalaRamirez et al. 2012). A clinical trial is needed to evaluate this therapeutic combination.

Finally, PT2977 - a potent inhibitor of HIF- $\alpha$ - has demonstrated antineoplastic effects in clear cell renal cell carcinomas, including occasional CR ( $\mathrm{Xu}$ et al. 2019). Observations in other malignancies, however, have shown that antiangiogenic therapies may at some point stimulate tumor invasion due to increased hypoxia, glycolysis, and induction of HIF- $\alpha$, despite vascular normalization (metabolic adaptation) (Keunen et al. 2011, Fack et al. 2015). Combining PT2977 with antiangiogenic drugs may lead to more impressive responses. Currently, the combination of cabozantinib with PT2977 is being evaluated in a phase 2 clinical trial for kidney cancer (NCT03634540).

\section{Conclusions}

Systemic therapy for MPPGs includes antiangiogenic medications. These drugs have antineoplastic effects, including tumor size reduction and disease stabilization, but have been associated with cardiovascular toxicity, especially in hormonally active tumors. The adverse effects from these medications, however, are in large part preventable and controllable. Antiangiogenic medications represent an alternative for patients with progressive disease and provide an opportunity to improve therapeutic interventions and clinical outcomes. To help ensure these outcomes, patients with MPPGs should be monitored and treated by a multidisciplinary team that is familiar with the oncological, hormonal, and pharmacologic aspects of this disease.

\section{Declaration of interest}

The authors declare that there is no conflict of interest that could be perceived as prejudicing the impartiality of this review.

\section{Funding}

This work did not receive any specific grant from any funding agency in the public, commercial, or not-for-profit sector.

\section{Author contribution statement}

All the authors contributed to the literature search, drafting of the manuscript, and critical review.

\section{Acknowledgements}

The authors are grateful to Catherine Cotten, Margaret Cazalot, Clarence Cazalot, Merle Granek, and the Team NAT Foundation for their contributions, which have made possible the development of new therapies for patients with MPPGs. Editorial support was provided by Tamara Locke in Scientific Publications, Research Medical Library at The University of Texas MD Anderson Cancer Center.

\section{References}

Aita Y, Ishii KA, Saito Y, Ikeda T, Kawakami Y, Shimano H, Hara H \& Takekoshi K 2012 Sunitinib inhibits catecholamine synthesis and secretion in pheochromocytoma tumor cells by blocking VEGF receptor 2 via PLC- $\gamma$-related pathways. American Journal of Physiology: Endocrinology and Metabolism 303 E1006-E1014. (https://doi. org/10.1152/ajpendo.00156.2012)

Allen E, Miéville P, Warren CM, Saghafinia S, Li L, Peng MW \& Hanahan D 2016 Metabolic symbiosis enables adaptive resistance to anti-angiogenic therapy that is dependent on mTOR signaling. Cell Reports 15 1144-1160. (https://doi.org/10.1016/j.celrep.2016.04.029)

Ayala-Ramirez M, Feng L, Johnson MM, Ejaz S, Habra MA, Rich T, Busaidy N, Cote GJ, Perrier N, Phan A, et al. 2011 Clinical risk factors for malignancy and overall survival in patients with pheochromocytomas and sympathetic paragangliomas: primary tumor size and primary tumor location as prognostic indicators. Journal of Clinical Endocrinology and Metabolism 96 717-725. (https:// doi.org/10.1210/jc.2010-1946)

Ayala-Ramirez M, Chougnet CN, Habra MA, Palmer JL, Leboulleux S, Cabanillas ME, Caramella C, Anderson P, Al Ghuzlan A,
(C) 2020 Society for Endocrinology Published by Bioscientifica Ltd. Printed in Great Britain 
Waguespack SG, et al. 2012 Treatment with sunitinib for patients with progressive metastatic pheochromocytomas and sympathetic paragangliomas. Journal of Clinical Endocrinology and Metabolism 97 4040-4050. (https://doi.org/10.1210/jc.2012-2356)

Ayala-Ramirez M, Palmer JL, Hofmann MC, de la Cruz M, Moon BS, Waguespack SG, Habra MA \& Jimenez C 2013 Bone metastases and skeletal-related events in patients with malignant pheochromocytoma and sympathetic paraganglioma. Journal of Clinical Endocrinology and Metabolism 98 1492-1497. (https://doi. org/10.1210/jc.2012-4231)

Bergers G \& Hanahan D 2008 Modes of resistance to anti-angiogenic therapy. Nature Reviews: Cancer 8 592-603. (https://doi.org/10.1038/ $\operatorname{nrc2442)}$

Białas M, Dyduch G, Dudała J, Bereza-Buziak M, HubalewskaDydejczyk A, Budzyński A \& Okoń K 2014 Study of microvessel density and the expression of vascular endothelial growth factors in adrenal gland pheochromocytomas. International Journal of Endocrinology 2014 104129. (https://doi.org/10.1155/2014/104129)

Brugarolas J, Lei K, Hurley RL, Manning BD, Reiling JH, Hafen E, Witters LA, Ellisen LW \& Kaelin WG 2004 Regulation of mTOR function in response to hypoxia by REDD1 and the TSC1/TSC2 tumor suppressor complex. Genes and Development 18 2893-2904. (https://doi.org/10.1101/gad.1256804)

Burotto Pichun ME, Edgerly M, Velarde M, Bates SE, Daerr R, Adams K, Pacak K \& Fojo T 2015 Phase II clinical trial of axitinib in metastatic pheochromocytomas and paragangliomas (P/PG): preliminary results. Journal of Clinical Oncology 33 457. (https://doi.org/10.1200/ jco.2015.33.7_suppl.457)

Calsina B, Castro-Vega LJ, Torres-Pérez R, Inglada-Pérez L, CurrásFreixes M, Roldán-Romero JM, Mancikova V, Letón R, Remacha L, Santos M, et al. 2019 Integrative multi-omics analysis identifies a prognostic miRNA signature and a targetable miR-21-3p/TSC2/mTOR axis in metastatic pheochromocytoma/paraganglioma. Theranostics 9 4946-4958. (https://doi.org/10.7150/thno.35458)

Carmeliet P \& Jain RK 2011 Principles and mechanisms of vessel normalization for cancer and other angiogenic diseases. Nature Reviews: Drug Discovery 10 417-427. (https://doi.org/10.1038/ nrd3455)

Castro-Vega LJ, Letouzé E, Burnichon N, Buffet A, Disderot PH, Khalifa E, Loriot C, Elarouci N, Morin A, Menara M, et al. 2015 Multi-omics analysis defines core genomic alterations in pheochromocytomas and paragangliomas. Nature Communications 6 6044. (https://doi.org/10.1038/ncomms7044)

Choueiri TK, Halabi S, Sanford BL, Hahn O, Michaelson MD, Walsh MK, Feldman DR, Olencki T, Picus J, Small EJ, et al. 2017 Cabozantinib versus sunitinib as initial targeted therapy for patients with metastatic renal cell carcinoma of poor or intermediate risk: the Alliance A031203 CABOSUN Trial. Journal of Clinical Oncology 35 591-597. (https://doi.org/10.1200/ JCO.2016.70.7398)

Claffey KP, Wilkison WO \& Spiegelman BM 1992 Vascular endothelial growth factor. Regulation by cell differentiation and activated second messenger pathways. Journal of Biological Chemistry 267 16317-16322.

Crona J, Delgado Verdugo A, Maharjan R, Stålberg P, Granberg D, Hellman P \& Björklund P 2013 Somatic mutations in H-RAS in sporadic pheochromocytoma and paraganglioma identified by exome sequencing. Journal of Clinical Endocrinology and Metabolism 98 E1266-E1271. (https://doi.org/10.1210/jc.2012-4257)

Dahia PL 2014 Pheochromocytoma and paraganglioma pathogenesis: learning from genetic heterogeneity. Nature Reviews: Cancer $\mathbf{1 4}$ 108-119. (https://doi.org/10.1038/nrc3648)

Dahia PL, Ross KN, Wright ME, Hayashida CY, Santagata S, Barontini M, Kung AL, Sanso G, Powers JF, Tischler AS, et al. 2005 A HIF1alpha regulatory loop links hypoxia and mitochondrial signals in pheochromocytomas. PLoS Genetics 1 72-80. (https://doi. org/10.1371/journal.pgen.0010008)

Dahia PLM, Clifton-Bligh R, Gimenez-Roqueplo A-P, Robledo M \& Jimenez C 2020 HEREDITARY ENDOCRINE TUMOURS: CURRENT STATE-OF-THE-ART AND RESEARCH OPPORTUNITIES: Metastatic pheochromocytoma and paraganglioma: proceedings of the MEN2019 workshop. Endocrine-Related Cancer [epub]. (https://doi. org/10.1530/ERC-19-0435)

Denorme M, Yon L, Roux C, Gonzalez BJ, Baudin E, Anouar Y \& Dubessy C 2014 Both sunitinib and sorafenib are effective treatments for pheochromocytoma in a xenograft model. Cancer Letters 352 236-244. (https://doi.org/10.1016/j.canlet.2014.07.005)

Diekstra MH, Klümpen HJ, Lolkema MP, Yu H, Kloth JS, Gelderblom H, van Schaik RH, Gurney H, Swen JJ, Huitema AD, et al. 2014 Association analysis of genetic polymorphisms in genes related to sunitinib pharmacokinetics, specifically clearance of sunitinib and SU12662. Clinical Pharmacology and Therapeutics 96 81-89. (https:// doi.org/10.1038/clpt.2014.47)

Facchin C, Perez-Liva M, Garofalakis A, Viel T, Certain A, Balvay D, Yoganathan T, Woszczyk J, De Sousa K, Sourdon J, et al. 2020 Concurrent imaging of vascularization and metabolism in a mouse model of paraganglioma under anti-angiogenic treatment. Theranostics 10 3518-3532. (https://doi.org/10.7150/thno.40687)

Fack F, Espedal H, Keunen O, Golebiewska A, Obad N, Harter PN, Mittelbronn M, Bähr O, Weyerbrock A, Stuhr L, et al. 2015 Bevacizumab treatment induces metabolic adaptation toward anaerobic metabolism in glioblastomas. Acta Neuropathologica 129 115-131. (https://doi.org/10.1007/s00401-014-1352-5)

Favier J \& Gimenez-Roqueplo AP 2010 Pheochromocytomas: the (pseudo)-hypoxia hypothesis. Best Practice and Research: Clinical Endocrinology and Metabolism 24 957-968. (https://doi.org/10.1016/j. beem.2010.10.004)

Favier J, Plouin PF, Corvol P \& Gasc JM 2002 Angiogenesis and vascular architecture in pheochromocytomas: distinctive traits in malignant tumors. American Journal of Pathology 161 1235-1246. (https://doi. org/10.1016/S0002-9440(10)64400-8)

Favier J, Igaz P, Burnichon N, Amar L, Libé R, Badoual C, Tissier F, Bertherat J, Plouin PF, Jeunemaitre X, et al. 2012 Rationale for antiangiogenic therapy in pheochromocytoma and paraganglioma. Endocrine Pathology 23 34-42. (https://doi.org/10.1007/s12022-0119189-0)

Favier J, Amar L \& Gimenez-Roqueplo AP 2015 Paraganglioma and phaeochromocytoma: from genetics to personalized medicine. Nature Reviews: Endocrinology 11 101-111. (https://doi.org/10.1038/ nrendo.2014.188)

Faivre S, Niccoli P, Castellano D, Valle JW, Hammel P, Raoul JL, Vinik A, Van Cutsem E, Bang YJ, Lee SH, et al. 2017 Sunitinib in pancreatic neuroendocrine tumors: updated progression-free survival and final overall survival from a phase III randomized study. Annals of Oncology 28 339-343. (https://doi.org/10.1093/annonc/mdw561)

Ferreira CV, Siqueira DR, Romitti M, Ceolin L, Brasil BA, Meurer L, Capp C \& Maia AL 2014 Role of VEGF-A and its receptors in sporadic and MEN2-associated pheochromocytoma. International Journal of Molecular Sciences 15 5323-5336. (https://doi.org/10.3390/ ijms15045323)

Fishbein L, Leshchiner I, Walter V, Danilova L, Robertson AG, Johnson AR, Lichtenberg TM, Murray BA, Ghayee HK, Else T, et al. 2017 Comprehensive molecular characterization of pheochromocytoma and paraganglioma. Cancer Cell 31 181-193. (https://doi.org/10.1016/j.ccell.2017.01.001)

Folkman J 1971 Tumor angiogenesis: therapeutic implications. New England Journal of Medicine 285 1182-1186. (https://doi.org/10.1056/ NEJM197111182852108)

García-Donas J, Beuselinck B, Inglada-Pérez L, Graña O, Schöffski P, Wozniak A, Bechter O, Apellániz-Ruiz M, Leandro-García LJ, (c) 2020 Society for Endocrinology Published by Bioscientifica Ltd. Printed in Great Britain 
Esteban E, et al. 2016 Deep sequencing reveals microRNAs predictive of antiangiogenic drug response. JCI Insight 1 e86051. (https://doi. org/10.1172/jci.insight.86051)

Gherardi E, Birchmeier W, Birchmeier C \& Vande Woude G 2012 Targeting MET in cancer: rationale and progress. Nature Reviews: Cancer 12 89-103. (https://doi.org/10.1038/nrc3205)

Gimenez-Roqueplo AP, Favier J, Rustin P, Rieubland C, Kerlan V, Plouin PF, Rötig A \& Jeunemaitre X 2002 Functional consequences of a SDHB gene mutation in an apparently sporadic pheochromocytoma. Journal of Clinical Endocrinology and Metabolism 87 4771-4774. (https://doi.org/10.1210/jc.2002-020525)

Goel S, Duda DG, Xu L, Munn LL, Boucher Y, Fukumura D \& Jain RK 2011 Normalization of the vasculature for treatment of cancer and other diseases. Physiological Reviews 91 1071-1121. (https://doi. org/10.1152/physrev.00038.2010)

Goncalves J, Lussey-Lepoutre C, Favier J, Gimenez-Roqueplo AP \& Castro-Vega LJ 2019 Emerging molecular markers of metastatic pheochromocytomas and paragangliomas. Annales d'Endocrinologie 80 159-162. (https://doi.org/10.1016/j.ando.2019.04.003)

Griffioen AW, Damen CA, Blijham GH \& Groenewegen G 1996 Tumor angiogenesis is accompanied by a decreased inflammatory response of tumor-associated endothelium. Blood 88 667-673. (https://doi. org/10.1182/blood.V88.2.667.bloodjournal882667)

Hamidi O, Young WF, Iñiguez-Ariza NM, Kittah NE, Gruber L, Bancos C, Tamhane S \& Bancos I 2017 Malignant pheochromocytoma and paraganglioma: 272 patients over 55 years. Journal of Clinical Endocrinology and Metabolism 102 3296-3305. (https://doi. org/10.1210/jc.2017-00992)

Hanahan D \& Folkman J 1996 Patterns and emerging mechanisms of the angiogenic switch during tumorigenesis. Cell 86 353-364. (https://doi.org/10.1016/s0092-8674(00)80108-7)

Hanahan D \& Weinberg RA 2011 Hallmarks of cancer: the next generation. Cell 144 646-674. (https://doi.org/10.1016/j. cell.2011.02.013)

Hao Z \& Wang P 2020 Lenvatinib in management of solid tumors. Oncologist 25 e302-e310. (https://doi.org/10.1634/ theoncologist.2019-0407)

Jasim S \& Jimenez C 2019 Metastatic pheochromocytoma and paraganglioma: management of endocrine manifestations, surgery and ablative procedures, and systemic therapies. Best Practice and Research: Clinical Endocrinology and Metabolism [epub]. (https://doi. org/10.1016/j.beem.2019.101354)

Jasim S, Chintakuntlawar A \& Ashish KC 2016 Durable response to lenvatinib in progressive, therapy-refractory, metastatic paraganglioma. International Journal of Endocrine Oncology 3 5-12. (https://doi.org/10.2217/ije-2016-0015)

Jasim S, Suman VJ, Jimenez C, Harris P, Sideras K, Burton JK, Worden FP, Auchus RJ \& Bible KC 2017 Phase II trial of pazopanib in advanced/ progressive malignant pheochromocytoma and paraganglioma. Endocrine 57 220-225. (https://doi.org/10.1007/s12020-017-1359-5)

Jayson GC, Hicklin DJ \& Ellis LM 2012 Antiangiogenic therapy evolving view based on clinical trial results. Nature Reviews: Clinical Oncology 9 297-303. (https://doi.org/10.1038/nrclinonc.2012.8)

Jimenez C 2018 Treatment for patients with malignant pheochromocytomas and paragangliomas: a perspective From the hallmarks of cancer. Frontiers in Endocrinology 9 277. (https://doi. org/10.3389/fendo.2018.00277)

Jimenez C, Cabanillas ME, Santarpia L, Jonasch E, Kyle KL, Lano EA, Matin SF, Nunez RF, Perrier ND, Phan A, et al. 2009 Use of the tyrosine kinase inhibitor sunitinib in a patient with von HippelLindau disease: targeting angiogenic factors in pheochromocytoma and other von Hippel-Lindau disease-related tumors. Journal of Clinical Endocrinology and Metabolism 94 386-391. (https://doi. org/10.1210/jc.2008-1972)

Jimenez C, Rohren E, Habra MA, Rich T, Jimenez P, Ayala-Ramirez M \& Baudin E 2013 Current and future treatments for malignant pheochromocytoma and sympathetic paraganglioma. Current Oncology Reports 15 356-371. (https://doi.org/10.1007/s11912-0130320-x)

Jimenez P, Tatsui C, Jessop A, Thosani S \& Jimenez C 2017 Treatment for malignant pheochromocytomas and paragangliomas: 5 years of progress. Current Oncology Reports 19 83. (https://doi.org/10.1007/ s11912-017-0643-0)

Job S, Draskovic I, Burnichon N, Buffet A, Cros J, Lépine C, Venisse A, Robidel E, Verkarre V, Meatchi T, et al. 2019 Telomerase activation and ATRX mutations are independent risk factors for metastatic pheochromocytoma and paraganglioma. Clinical Cancer Research $\mathbf{2 5}$ 760-770. (https://doi.org/10.1158/1078-0432.CCR-18-0139)

Jonasch E, McCutcheon IE, Waguespack SG, Wen S, Davis DW, Smith LA, Tannir NM, Gombos DS, Fuller GN \& Matin SF 2011 Pilot trial of sunitinib therapy in patients with von Hippel-Lindau disease. Annals of Oncology 22 2661-2666. (https://doi.org/10.1093/annonc/ mdr011)

Joshua AM, Ezzat S, Asa SL, Evans A, Broom R, Freeman M \& Knox JJ 2009 Rationale and evidence for sunitinib in the treatment of malignant paraganglioma/pheochromocytoma. Journal of Clinical Endocrinology and Metabolism 94 5-9. (https://doi.org/10.1210/ jc.2008-1836)

Jung KO, Youn H, Lee CH, Kang KW \& Chung JK 2017 Visualization of exosome-mediated miR-210 transfer from hypoxic tumor cells. Oncotarget 8 9899-9910. (https://doi.org/10.18632/oncotarget.14247)

Keunen O, Johansson M, Oudin A, Sanzey M, Rahim SA, Fack F, Thorsen F, Taxt T, Bartos M, Jirik R, et al. 2011 Anti-VEGF treatment reduces blood supply and increases tumor cell invasion in glioblastoma. PNAS 108 3749-3754. (https://doi.org/10.1073/ pnas.1014480108)

Lam AK 2017 Update on adrenal tumours in 2017 World Health Organization (WHO) of endocrine tumours. Endocrine Pathology 28 213-227. (https://doi.org/10.1007/s12022-017-9484-5)

Land SC \& Tee AR 2007 Hypoxia-inducible factor 1alpha is regulated by the mammalian target of rapamycin (mTOR) via an mTOR signaling motif. Journal of Biological Chemistry 282 20534-20543. (https://doi. org/10.1074/jbc.M611782200)

Lenders JW, Duh QY, Eisenhofer G, Gimenez-Roqueplo AP, Grebe SK, Murad MH, Naruse M, Pacak K, Young WF \& Society E 2014 Pheochromocytoma and paraganglioma: an endocrine society clinical practice guideline. Journal of Clinical Endocrinology and Metabolism 99 1915-1942. (https://doi.org/10.1210/jc.2014-1498)

Lim JH, Lee ES, You HJ, Lee JW, Park JW \& Chun YS 2004 Rasdependent induction of HIF-1alpha785 via the Raf/MEK/ERK pathway: a novel mechanism of Ras-mediated tumor promotion. Oncogene 23 9427-9431. (https://doi.org/10.1038/sj.onc.1208003)

Liu Q, Djuricin G, Staren ED, Gattuso P, Gould VE, Shen J, Saclarides T, Rubin DB \& Prinz RA 1996 Tumor angiogenesis in pheochromocytomas and paragangliomas. Surgery 120 938-942; discussion 942-933. (https://doi.org/10.1016/s0039-6060(96)80037-7)

Liu N, Ding D, Hao W, Yang F, Wu X, Wang M, Xu X, Ju Z, Liu JP, Song $\mathrm{Z}$, et al. $2016 \mathrm{hTERT}$ promotes tumor angiogenesis by activating VEGF via interactions with the $\mathrm{Sp} 1$ transcription factor. Nucleic Acids Research 44 8693-8703. (https://doi.org/10.1093/nar/ gkw549)

Lugano R, Ramachandran M \& Dimberg A 2020 Tumor angiogenesis: causes, consequences, challenges and opportunities. Cellular and Molecular Life Sciences 77 1745-1770. (https://doi.org/10.1007/ s00018-019-03351-7)

Lussey-Lepoutre C, Buffet A, Morin A, Goncalves J \& Favier J 2018 Rodent models of pheochromocytoma, parallels in rodent and human tumorigenesis. Cell and Tissue Research 372 379-392. (https:// doi.org/10.1007/s00441-018-2797-y)

Makis W, McCann K, McEwan AJ \& Sawyer MB 2016 Combined treatment with 131I-MIBG and sunitinib induces remission in a patient with metastatic paraganglioma due to hereditary 
paraganglioma-pheochromocytoma syndrome from an SDHB mutation. Clinical Nuclear Medicine 41 204-206. (https://doi. org/10.1097/RLU.0000000000000973)

Manegold C, Dingemans AC, Gray JE, Nakagawa K, Nicolson M, Peters S, Reck M, Wu YL, Brustugun OT, Crinò L, et al. 2017 The potential of combined immunotherapy and antiangiogenesis for the synergistic treatment of advanced NSCLC. Journal of Thoracic Oncology 12 194-207. (https://doi.org/10.1016/j.jtho.2016.10.003)

Manger WM 2009 The protean manifestations of pheochromocytoma. Hormone and Metabolic Research 41 658-663. (https://doi. org/10.1055/s-0028-1128139)

Mannelli M, Rapizzi E, Fucci R, Canu L, Ercolino T, Luconi M \& Young WF 201515 YEARS OF PARAGANGLIOMA: Metabolism and pheochromocytoma/paraganglioma. Endocrine-Related Cancer 22 T83-T90. (https://doi.org/10.1530/ERC-15-0215)

Mazzone M, Dettori D, de Oliveira RL, Loges S, Schmidt T, Jonckx B, Tian YM, Lanahan AA, Pollard P, de Almodovar CR, et al. 2009 Heterozygous deficiency of PHD2 restores tumor oxygenation and inhibits metastasis via endothelial normalization. Cell 136 839-851. (https://doi.org/10.1016/j.cell.2009.01.020)

Middeke M, Hoffmann S, Hassan I, Wunderlich A, Hofbauer LC \& Zielke A 2002 In vitro and in vivo angiogenesis in PC12 pheochromocytoma cells is mediated by vascular endothelial growth factor. Experimental and Clinical Endocrinology and Diabetes 110 386-392. (https://doi.org/10.1055/s-2002-36424)

Motzer RJ, Hutson TE, Tomczak P, Michaelson MD, Bukowski RM, Rixe O, Oudard S, Negrier S, Szczylik C, Kim ST, et al. 2007 Sunitinib versus interferon alfa in metastatic renal-cell carcinoma. New England Journal of Medicine 356 115-124. (https://doi.org/10.1056/ NEJMoa065044)

Motzer RJ, Hutson TE, Cella D, Reeves J, Hawkins R, Guo J, Nathan P, Staehler M, de Souza P, Merchan JR, et al. 2013 Pazopanib versus sunitinib in metastatic renal-cell carcinoma. New England Journal of Medicine 369 722-731. (https://doi.org/10.1056/NEJMoa1303989)

Motzer RJ, Penkov K, Haanen J, Rini B, Albiges L, Campbell MT, Venugopal B, Kollmannsberger C, Negrier S, Uemura M, et al. 2019 Avelumab plus axitinib versus sunitinib for advanced renal-cell carcinoma. New England Journal of Medicine 380 1103-1115. (https:// doi.org/10.1056/NEJMoa1816047)

Obad N, Espedal H, Jirik R, Sakariassen PO, Brekke Rygh C, LundJohansen M, Taxt T, Niclou SP, Bjerkvig R \& Keunen O 2018 Lack of functional normalisation of tumour vessels following anti-angiogenic therapy in glioblastoma. Journal of Cerebral Blood Flow and Metabolism 38 1741-1753. (https://doi.org/10.1177/0271678X17714656)

Oh DY, Kim TW, Park YS, Shin SJ, Shin SH, Song EK, Lee HJ, Lee KW \& Bang YJ 2012 Phase 2 study of everolimus monotherapy in patients with nonfunctioning neuroendocrine tumors or pheochromocytomas/paragangliomas. Cancer 118 6162-6170. (https://doi.org/10.1002/cncr.27675)

Ohji H, Sasagawa I, Iciyanagi O, Suzuki Y \& Nakada T 2001 Tumour angiogenesis and Ki-67 expression in phaeochromocytoma. BJU International 87 381-385. (https://doi. org/10.1046/j.1464-410x.2001.00102.x)

O'Kane GM, Ezzat S, Joshua AM, Bourdeau I, Leibowitz-Amit R, Olney HJ, Krzyzanowska M, Reuther D, Chin S, Wang L, et al. 2019 A phase 2 trial of sunitinib in patients with progressive paraganglioma or pheochromocytoma: the SNIPP trial. British Journal of Cancer 120 1113-1119. (https://doi.org/10.1038/s41416-019-0474-x)

Oudijk L, van Nederveen F, Badoual C, Tissier F, Tischler AS, Smid M, Gaal J, Lepoutre-Lussey C, Gimenez-Roqueplo AP, Dinjens WN, et al. 2015 Vascular pattern analysis for the prediction of clinical behaviour in pheochromocytomas and paragangliomas. PLOS ONE 10 e0121361. (https://doi.org/10.1371/journal.pone.0121361)

Oudijk L, Papathomas T, de Krijger R, Korpershoek E, GimenezRoqueplo AP, Favier J, Canu L, Mannelli M, Rapa I, Currás-Freixes M, et al. 2017 The mTORC1 complex is significantly overactivated in
SDHX-mutated paragangliomas. Neuroendocrinology 105 384-393. (https://doi.org/10.1159/000455864)

Parikh PP, Rubio GA, Farra JC \& Lew JI 2017 Nationwide review of hormonally active adrenal tumors highlights high morbidity in pheochromocytoma. Journal of Surgical Research 215 204-210. (https://doi.org/10.1016/j.jss.2017.04.011)

Pozas J, San Román M, Alonso-Gordoa T, Pozas M, Caracuel L, Carrato A \& Molina-Cerrillo J 2019 Targeting angiogenesis in pancreatic neuroendocrine tumors: resistance mechanisms. International Journal of Molecular Sciences 20 E4949. (https://doi.org/10.3390/ ijms20194949)

Preissner SC, Hoffmann MF, Preissner R, Dunkel M, Gewiess A \& Preissner S 2013 Polymorphic cytochrome P450 enzymes (CYPs) and their role in personalized therapy. PLOS ONE 8 e82562. (https://doi. org/10.1371/journal.pone.0082562)

Pryma DA, Chin BB, Noto RB, Dillon JS, Perkins S, Solnes L, Kostakoglu L, Serafini AN, Pampaloni MH, Jensen J, et al. 2019 Efficacy and safety of high-specific-activity I-131 MIBG therapy in patients with advanced pheochromocytoma or paraganglioma. Journal of Nuclear Medicine 60 623-630. (https://doi.org/10.2967/ jnumed.118.217463)

Pugh CW \& Ratcliffe PJ 2003 Regulation of angiogenesis by hypoxia: role of the HIF system. Nature Medicine 9 677-684. (https://doi. org/10.1038/nm0603-677)

Richard DE, Berra E, Gothié E, Roux D \& Pouysségur J 1999 p42/p44 mitogen-activated protein kinases phosphorylate hypoxia-inducible factor 1alpha (HIF-1alpha) and enhance the transcriptional activity of HIF-1. Journal of Biological Chemistry 274 32631-32637. (https:// doi.org/10.1074/jbc.274.46.32631)

Rini BI, Melichar B, Ueda T, Grünwald V, Fishman MN, Arranz JA, Bair AH, Pithavala YK, Andrews GI, Pavlov D, et al. 2013 Axitinib with or without dose titration for first-line metastatic renal-cell carcinoma: a randomised double-blind phase 2 trial. Lancet: Oncology 14 1233-1242. (https://doi.org/10.1016/S14702045(13)70464-9)

Roman-Gonzalez A \& Jimenez C 2017 Malignant pheochromocytomaparaganglioma: pathogenesis, TNM staging, and current clinical trials. Current Opinion in Endocrinology, Diabetes, and Obesity 24 174-183. (https://doi.org/10.1097/MED.0000000000000330)

Roman-Gonzalez A, Zhou S, Ayala-Ramirez M, Shen C, Waguespack SG, Habra MA, Karam JA, Perrier N, Wood CG \& Jimenez C 2018 Impact of surgical resection of the primary tumor on overall survival in patients with metastatic pheochromocytoma or sympathetic paraganglioma. Annals of Surgery 268 172-178. (https://doi. org/10.1097/SLA.0000000000002195)

Rooijens PP, de Krijger RR, Bonjer HJ, van der Ham F, Nigg AL, Bruining HA, Lamberts SW \& van der Harst E 2004 The significance of angiogenesis in malignant pheochromocytomas. Endocrine Pathology 15 39-45. (https://doi.org/10.1385/ep:15:1:39)

Saito Y, Tanaka Y, Aita Y, Ishii KA, Ikeda T, Isobe K, Kawakami Y, Shimano H, Hara H \& Takekoshi K 2012 Sunitinib induces apoptosis in pheochromocytoma tumor cells by inhibiting VEGFR2/Akt/ mTOR/S6K1 pathways through modulation of Bcl-2 and BAD. American Journal of Physiology: Endocrinology and Metabolism 302 E615-E625. (https://doi.org/10.1152/ajpendo.00035.2011)

Sakurai T \& Kudo M 2011 Signaling pathways governing tumor angiogenesis. Oncology 81 (Supplement 1) 24-29. (https://doi. org/10.1159/000333256)

Salmenkivi K, Heikkilä P, Liu J, Haglund C \& Arola J 2003 VEGF in 105 pheochromocytomas: enhanced expression correlates with malignant outcome. APMIS 111 458-464. (https://doi. org/10.1034/j.1600-0463.2003.1110402.x)

Santoro M, Melillo RM, Carlomagno F, Fusco A \& Vecchio G 2002 Molecular mechanisms of RET activation in human cancer. Annals of the New York Academy of Sciences 963 116-121. (https://doi. org/10.1111/j.1749-6632.2002.tb04102.x) 
Sheehy AM, Phung YT, Riemer RK \& Black SM 1997 Growth factor induction of nitric oxide synthase in rat pheochromocytoma cells. Brain Research: Molecular Brain Research 52 71-77. (https://doi. org/10.1016/s0169-328x(97)00224-6)

Shrimali RK, Yu Z, Theoret MR, Chinnasamy D, Restifo NP \& Rosenberg SA 2010 Antiangiogenic agents can increase lymphocyte infiltration into tumor and enhance the effectiveness of adoptive immunotherapy of cancer. Cancer Research 70 6171-6180. (https:// doi.org/10.1158/0008-5472.CAN-10-0153)

Smith M, De Bono J, Sternberg C, Le Moulec S, Oudard S, De Giorgi U, Krainer M, Bergman A, Hoelzer W, De Wit R, et al. 2016 Phase III study of cabozantinib in previously treated metastatic castrationresistant prostate cancer: COMET-1. Journal of Clinical Oncology 34 3005-3013. (https://doi.org/10.1200/JCO.2015.65.5597)

Takekoshi K, Isobe K, Yashiro T, Hara H, Ishii K, Kawakami Y, Nakai T \& Okuda Y 2004 Expression of vascular endothelial growth factor (VEGF) and its cognate receptors in human pheochromocytomas. Life Sciences 74 863-871. (https://doi.org/10.1016/j. lfs.2003.07.036)

Taylor MH, Lee CH, Makker V, Rasco D, Dutcus CE, Wu J, Stepan DE, Shumaker RC \& Motzer RJ 2020 Phase IB/II trial of lenvatinib plus pembrolizumab in patients with advanced renal cell carcinoma, endometrial cancer, and other selected advanced solid tumors. Journal of Clinical Oncology 38 1154-1163. (https://doi.org/10.1200/ JCO.19.01598)

Thosani S, Ayala-Ramirez M, Palmer L, Hu MI, Rich T, Gagel RF, Cote G, Waguespack SG, Habra MA \& Jimenez C 2013 The characterization of pheochromocytoma and its impact on overall survival in multiple endocrine neoplasia type 2. Journal of Clinical Endocrinology and Metabolism 98 E1813-E1819. (https://doi.org/10.1210/jc.2013-1653)

Thosani S, Ayala-Ramirez M, Román-González A, Zhou S, Thosani N, Bisanz A \& Jimenez C 2015 Constipation: an overlooked, unmanaged symptom of patients with pheochromocytoma and sympathetic paraganglioma. European Journal of Endocrinology 173 377-387. (https://doi.org/10.1530/EJE-15-0456)

Toledo RA 2017 Genetics of pheochromocytomas and paragangliomas: an overview on the recently implicated genes MERTK, MET, fibroblast growth factor receptor 1, and H3F3A. Endocrinology and
Metabolism Clinics of North America 46 459-489. (https://doi. org/10.1016/j.ecl.2017.01.009)

Toledo RA, Qin Y, Cheng ZM, Gao Q, Iwata S, Silva GM, Prasad ML, Ocal IT, Rao S, Aronin N, et al. 2016 Recurrent mutations of chromatin-remodeling genes and kinase receptors in pheochromocytomas and paragangliomas. Clinical Cancer Research 22 2301-2310. (https://doi.org/10.1158/1078-0432.CCR-15-1841)

Trusolino L, Bertotti A \& Comoglio PM 2010 MET signalling: principles and functions in development, organ regeneration and cancer. Nature Reviews: Molecular Cell Biology 11 834-848. (https://doi. org/10.1038/nrm3012)

van Geel RM, Beijnen JH \& Schellens JH 2012 Concise drug review: pazopanib and axitinib. Oncologist 17 1081-1089. (https://doi. org/10.1634/theoncologist.2012-0055)

Varghese JC, Hahn PF, Papanicolaou N, Mayo-Smith WW, Gaa JA \& Lee MJ 1997 MR differentiation of phaeochromocytoma from other adrenal lesions based on qualitative analysis of T2 relaxation times. Clinical Radiology 52 603-606. (https://doi.org/10.1016/s00099260(97)80252-8)

Xu R, Wang K, Rizzi JP, Huang H, Grina JA, Schlachter ST, Wang B, Wehn PM, Yang H, Dixon DD, et al. 2019 3-[(1S,2S,3R)-2,3-Difluoro-1hydroxy-7-methylsulfonylindan-4-yl]oxy-5-fluorobenzonitrile (PT2977), a hypoxia-inducible factor $2 \alpha$ (HIF- $2 \alpha$ ) inhibitor for the treatment of clear cell renal cell carcinoma. Journal of Medicinal Chemistry 626876 6893. (https://doi.org/10.1021/acs.jmedchem.9b00719)

Zarrin B, Zarifi F, Vaseghi G \& Javanmard SH 2017 Acquired tumor resistance to antiangiogenic therapy: mechanisms at a glance. Journal of Research in Medical Sciences 22 117. (https://doi.org/10.4103/jrms. JRMS_182_17)

Zielke A, Middeke M, Hoffmann S, Colombo-Benkmann M, Barth P, Hassan I, Wunderlich A, Hofbauer LC \& Duh QY 2002 VEGFmediated angiogenesis of human pheochromocytomas is associated to malignancy and inhibited by anti-VEGF antibodies in experimental tumors. Surgery 132 1056-1063; discussion 1063. (https://doi.org/10.1067/msy.2002.128613)

Zschäbitz S \& Grüllich C 2018 Lenvantinib: a tyrosine kinase inhibitor of VEGFR 1-3, FGFR 1-4, PDGFR $\alpha$, KIT and RET. Recent Results in Cancer Research 211 187-198. (https://doi.org/10.1007/978-3-319-91442-8_13)

Received in final form 2 May 2020

Accepted 4 May 2020

Accepted Manuscript published online 5 May 2020 (c) 2020 Society for Endocrinology Published by Bioscientifica Ltd. Printed in Great Britain 